\title{
Changes of Land Cover in Diwaniyah Governorate and their Impact on Agricultural Sustainability by Using Geomatics Techniques.

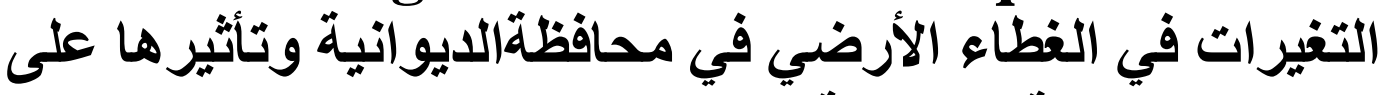 الإستدامة الزراعية بإستخدام تقنيات الجيوماتكس الإنية
}

\author{
ELMewafi, M. ${ }^{\text {a }}$, Kedy, S. K. ${ }^{\text {a,b }}$ and Elnaggar, A. A. ${ }^{c}$
}

${ }^{a}$ Department of Public Works, Faculty of Engineering, Mansoura University, Egypt

${ }^{\mathbf{b}}$ Department of Civil Engineering, University of Kufa, Iraq

${ }^{\mathbf{c}}$ Department of Soil Science, Faculty of Agriculture, Mansoura University, Egypt

Corresponding Author: Kedy,S. K., Email: theengali@yahoo.com

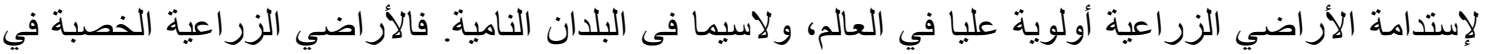

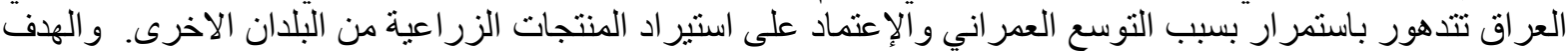

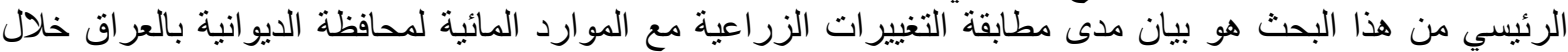

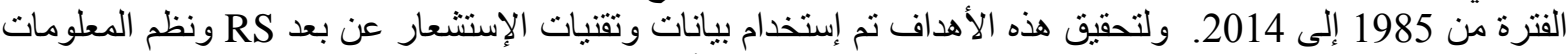

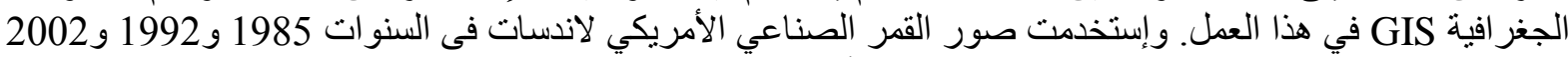

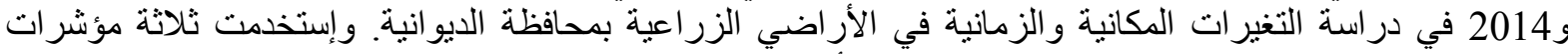

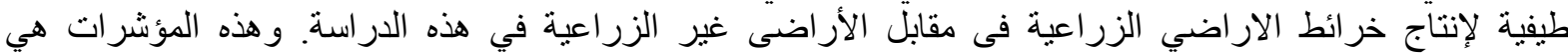

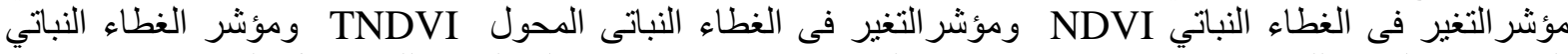

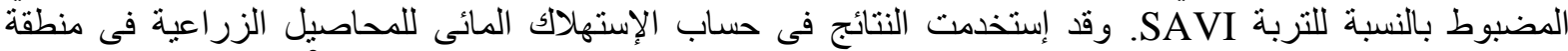

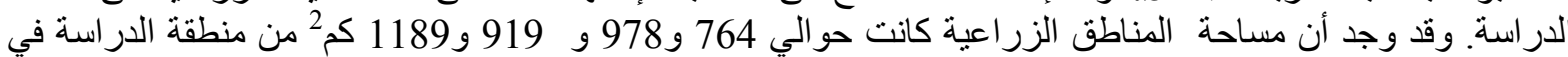

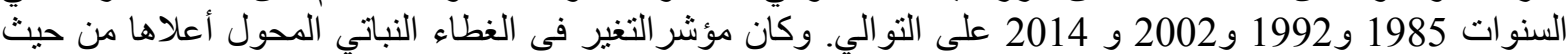

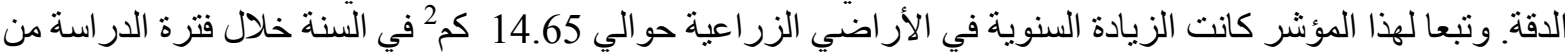

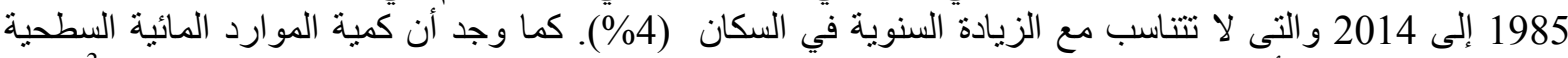

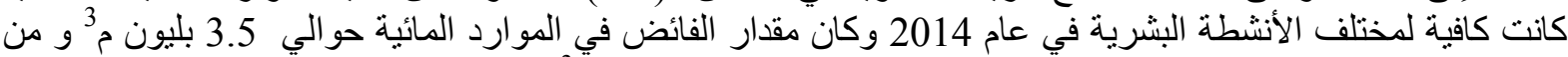

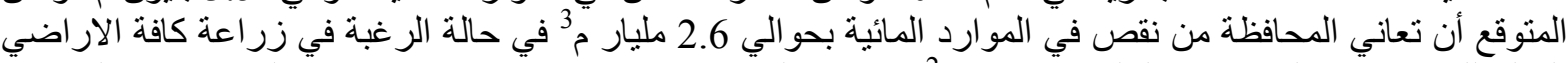

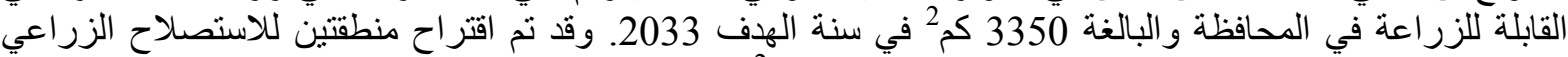
ليكون التخطيط للزيادة في مساحة الار اضي الزراعية 126 كم² سنويا لزر اعة كامل هذه المناطق بحلول العام 2033.

\begin{abstract}
Sustainability of agricultural lands has the highest priority worldwide and developing countries in particular. Fertile agricultural lands in Iraq are constantly deteriorating due to urbanization and importing agricultural products from other countries. The main objective of this work was to provide an accurate assessment of agricultural lands in Diwaniyah Governorate, Iraq during the studied period from 1985 to 2014.This was in addition to evaluating the availability of surface water resources for agricultural sustainability. For these purposes both Remote Sensing (RS) and Geographic information system (GIS) data and technology were integrated in this work. Landsat images in 1985, 1992, 2002 and 2014 were used to study spatial and temporal changes in agricultural lands in Diwaniyah Governorate. Three vegetation indices were used to map agricultural versus non- agricultural areas. These indices are the Normalized Difference Vegetation Index (NDVI), Transformed Normalized Difference Vegetation Index (TNDVI) and Soil Adjusted Vegetation Index (SAVI).The obtained results were used in calculating water consumption for agriculture crops in the studied area. It was found that agricultural areas represented about 764, 978, 919 and $1,198 \mathrm{~km}^{2}$ from the studied area in 1985, 1992, 2002 and 2014, respectively. It was found that the TNDVI had the highest accuracy and accordingly the annual increase in agricultural lands was about $14.65 \mathrm{~km}^{2}$ per year during the whole studied period from 1985 to 2014, which doesn't comply with the annual increase in population (4\%). Surface water
\end{abstract}


resources were sufficient for the different human activities in 2014. There was a surplus of water resources by about 3.5 billion $\mathrm{m}^{3}$. However, shortage in water resources by about 2.6 billion $\mathrm{m} 3$ is expected if the targeted arable lands are cultivated by 2033.Two large areas can be proposed for land reclamation in Diwaniyah Governorate; however the annual increase in agricultural land has to reach $126 \mathrm{~km}^{2}$ per year to cultivate these proposed areas by 2033 .

\section{Keywords}

Agricultural lands, Water resources, NDVI, SAVI, TNDVI, Change detection, Remote sensing, GIS.

\section{Introduction}

The concept of sustainable development is the most important policy of the $21^{\text {st }}$ century. It is a new paradigm of society, economics and the environment. It is regarded as a new philosophy, in which principles of futurity, equity, global environmentalism and biodiversity guide decision making. The concept is widely used in biology, economics, urban planning and other domains. Efforts towards sustainable development seek to establish a dynamic equilibrium among economic, environmental and social pillars [1]. Humanity has the ability to make sustainable development to ensure that it meets the needs of the present without compromising the ability of future [2].The solution for providing food security to all people of the world without affecting the agro- ecological balance lies in the adaptation of new research tools, particularly from aerospace Remote Sensing, and combining them with conventional as well as frontier technologies like Geographic Information Systems (GIS). Sustainable agricultural development is one of the prime objectives in all countries in the world, whether developed or developing. The broad objective of sustainable agriculture is to balance the inherent land resource with crop requirements, paying special attention to optimization of resource use towards achievement of sustained productivity over a long period. RS and GIS technology are being effectively utilized in several areas for sustainable agricultural development and management. The areas of sustainable agricultural development/ management include cropping system analysis; agroecological zonation; quantitative assessment of soil carbon dynamics and land productivity; soil erosion inventory; integrated agricultural drought assessment and management and Integrated Mission for Sustainable Development (IMSD) 3].

\section{Study Area and Data}

\subsection{Area and Location}

The study region is Diwaniyah Governorate. It is located to the middle south of Iraq as shown in figure (1), about $180 \mathrm{~km}$ south of Baghdad and $320 \mathrm{~km}$ north of Basra. It lies between Latitudes $30.5^{\circ}-32.5^{\circ} \mathrm{N}$, and Longitudes $44.5^{\circ}$ $46^{\circ} \mathrm{E}$, with a total area of about 8,786 $\mathrm{km}^{2}$. It has a population of about 1,275 million people in 2014. The maximum temperature in the studied area ranges between 26.5 and $46.8^{\circ} \mathrm{C}$, with an average value of about $36.5^{\circ} \mathrm{C}$. The minimum temperature varied from $3.0^{\circ} \mathrm{C}$ to $21.7^{\circ} \mathrm{C}$, with an average value of about $12.2^{\circ} \mathrm{C}$. August is the hottest month and January is the coldest. Mean annual precipitation is about $105.5 \mathrm{~mm}$ [4]. Geological formations in the Governorate consist of sedimentary plain, buried depressions, flat sand land, western plateau and Al-Dalmaj marsh [5]. The sedimentary plain represents the majority of the area (about $77 \%$ ), followed by the buried depressions (about 15\%). 


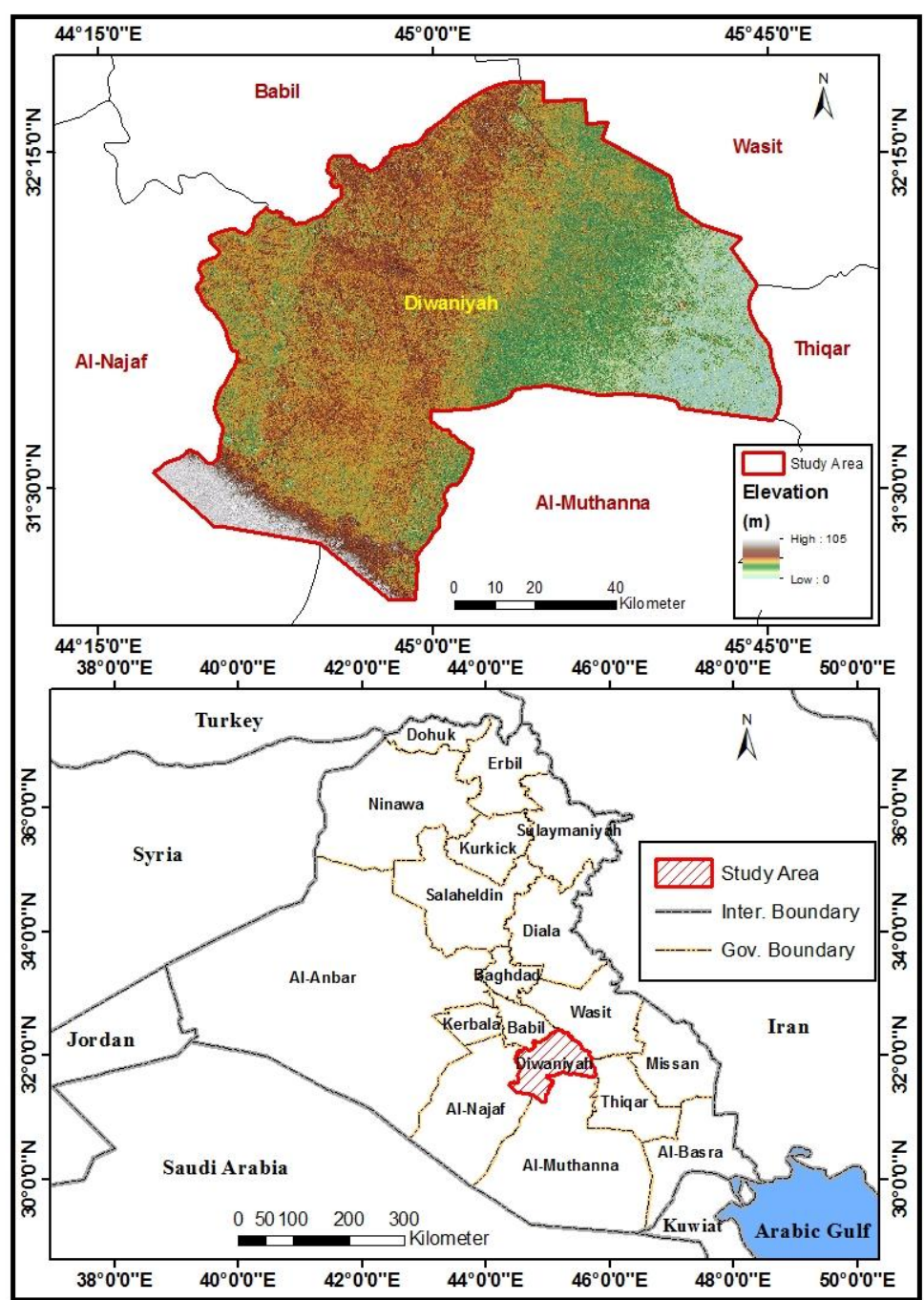

Figure (1): Location map of the study area in Iraq.

\subsection{Remote Sensing Data}

The studied area is covered by two Landsat images (path 167 and 168, row 38). The acquisition dates for the studied images are represented in table (1). Eight Landsat images were used to study the spatial and temporal changes in agricultural lands within Diwaniyah Governorate in 1985, 1992, 2002 and 2014. Each year is represented by two images. These images were downloaded from the earth explorer website developed by the United States Geological Survey (USGS): http://earthexplorer.usgs.gov/. All of the studied images were acquired during the summer months to have cloud free images and intensive vegetation covers.
Table (1): Acquisition dates of the studied Landsat images.

\begin{tabular}{|l|l|}
\hline Sensor Type & $\begin{array}{l}\text { Acquisition } \\
\text { Date }\end{array}$ \\
\hline Landsat 5 (TM) & $29 / 07 / 1985$ \\
\hline Landsat 4 (TM) & $09 / 08 / 1992$ \\
\hline Landsat 7 (ETM+) & $05 / 08 / 2002$ \\
\hline Landsat 8 (OLI-TIRS) & $14 / 08 / 2014$ \\
\hline
\end{tabular}

3. Digital image processing 3.1. Atmospheric and radiometric corrections

All of the studied Landsat images were atmospherically corrected by using the dark-object subtraction method in the ENVI software package. This was to 
reduce the atmospheric interferences (dust, haze, smoke, etc.). Also, the images were radio metrically corrected. In this process the Digital Number (DN) within each pixel was converted into at sensor reflectance based on the metadata associated with that image. The two images for each year were mosaicked to form a single image using the histogram matching process and resampled to have a $30 \mathrm{~m}$ pixel size. Each image mosaic for each of the four studied dates was subseted to cover Diwaniyah Governorate. A False Color Composite (FCC) of the studied images is illustrated in Figure (2).

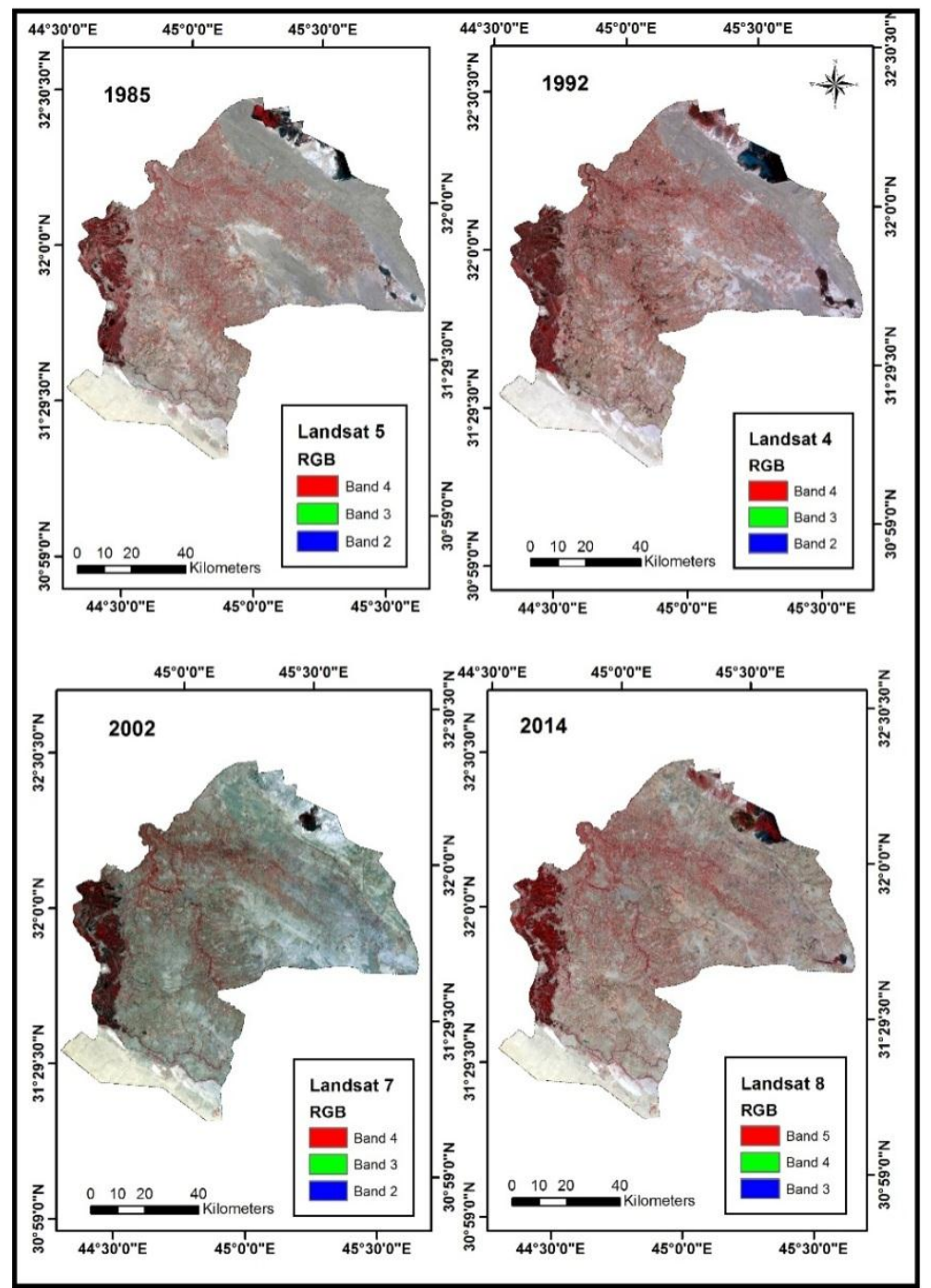

Figure (2): False Color Composite (FCC) of the studied Landsat images acquired in 1985, 1992, 2002 and 2014.

\subsection{Image Georectification}

The studied images were geometrically corrected using 16 ground control points (GCPs). The RMS error was very low (less than 0.5 of a pixel). All images were projected to have the same projection (UTM, Zone 38N, Datum WGS (1984) and a pixel size of 30 meters as shown figure (3). 


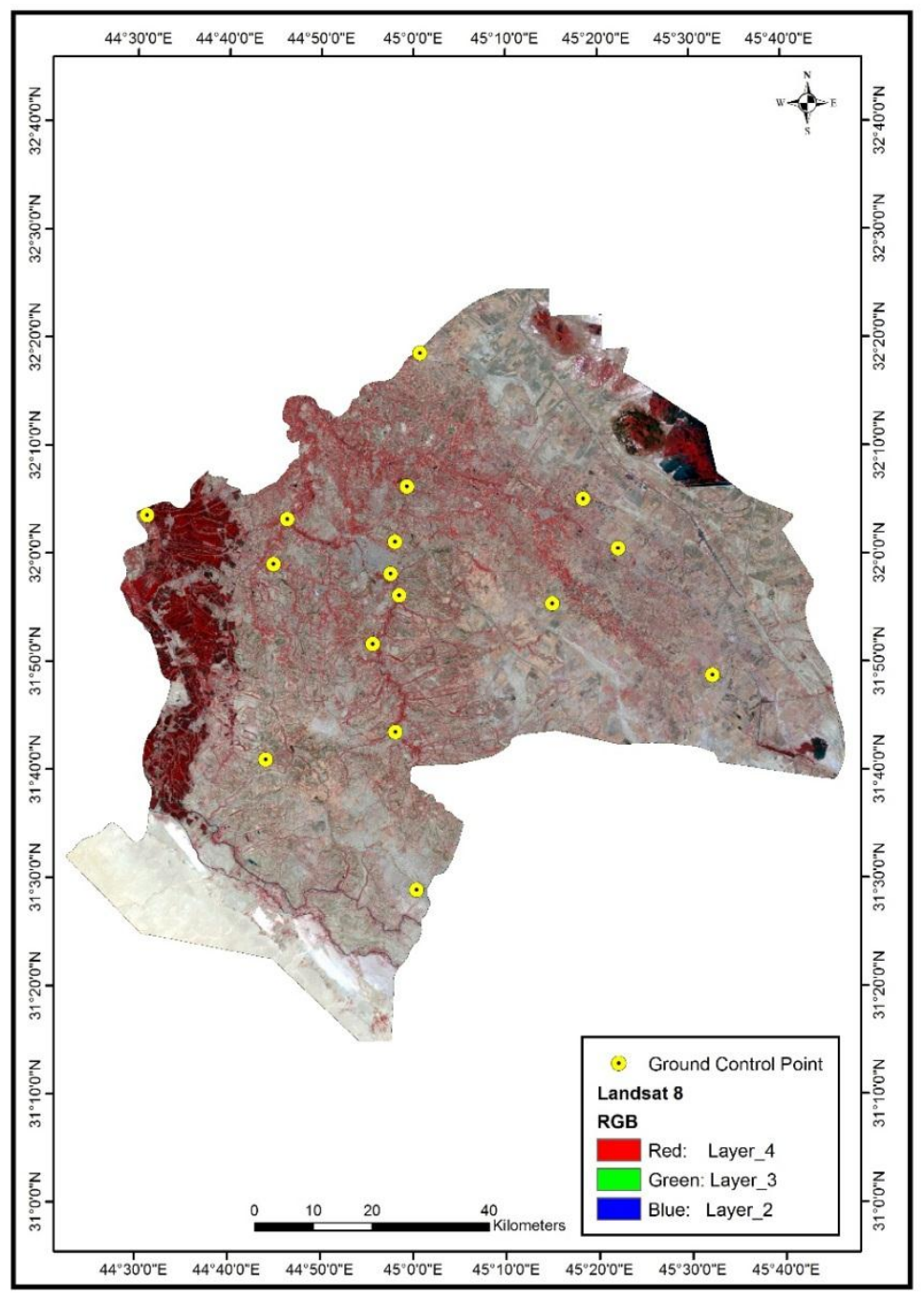

Figure 3.Ground control point.

\subsection{Spectral indices}

In this work, three different vegetation indexes were studied to evaluate the spatial and temporal changes in agricultural areas of Diwaniyah Governorate. These indices were the Normalized Difference Vegetation Index (NDVI), the Transformed Normalized Difference Vegetation Index (TNDVI), and the Soil Adjusted Vegetation Index (SAVI). These indices are used to quantify the concentrations of green leaf vegetation around the globe for biomass analysis. They depend on the reflectance of vegetation, which is very different in the near infrared and red bands. Healthy vegetation absorbs the visible spectrum and reflects most of the near infrared spectrum. On the other hand, unhealthy vegetation reflects more visible light and less near infrared spectrum. Spectral reflectance, in the visible range is associated with the chlorophyll pigments in plant leaves; however it depends on the cell structure in the near infrared portion of spectrum.

The NDVI is calculated using the following equation [6]:

NDVI $=(\mathbf{N I R}-\mathbf{R e d}) /(\mathbf{N I R}+\mathrm{Red})$

Where, NIR is the reflectance in the near infrared portion of spectrum and Red is the reflectance in the red portion of spectrum. NDVI values range between -1.0 and +1.0 , where positive values indicate healthy 
vegetation and near zero or negative values represent non-agricultural landcovers.

The TNDVI is the square root of the NDVI.

TNDVI $=[($ NIR - Red $) /($ NIR + Red $)] 1 / 2$

TNDVI indicates the relationship between the amounts of green biomass that is found in a pixel [7]. It has a higher coefficient of determination for the same variable and this is the difference between the TNDVI and NDVI. The formula of TNDVI has always positive values and the variances are proportional to mean values.

The SAVI is calculated using the following equation as described by [8]:

SAVI $=($ NIR - Red $) \times(1+$ L $) /($ NIR + Red + L)

Where: $\mathrm{L}$ is a correction factor ranging from 0 for very high plant densities to 1 for very low plant densities (a value of 0.5 was used in this work).

The difference between SAVI and NDVI is that SAVI is more sensitive than the NDVI in detecting vegetation in lowdensity agricultural areas such as urban and desert areas. The SAVI can work with areas that have a plant cover as low as $15 \%$, whereas the NDVI can work effectively in areas that have vegetation cover greater than 30\% [9]. Areas that represent open water, lakes, and sabkhas were excluded from this study. These areas were given a value of zero. The above mentioned indices were applied on the mosaics of 1985, 1992, 2002 and 2014 reflectance images. The obtained images were classified into binary classes based on the threshold value that separates the agricultural from the non-agricultural areas. Image manipulation techniques were carried out using both ERDAS Imagine 2014, Envi 5.1 and ArcGIS desktop 10.3 Software packages.

\subsection{Accuracy Assessment}

Accuracy Assessment was carried out on the obtained binary imaged from the three studied indices in 1985, 1992,
2002, and 2014 to determine how well each index accomplish the task. The classified image was compared with a variety of data such as aerial photographs, topographic maps, high resolution images and ground truth data for the 2014 images). The error matrix was developed for that purpose. It represents a table in which values that were assigned to each land use during the classification process (Barren $=0$ and Agriculture $=1$ ) were compared to the actual land cover from the mentioned sources of data. These were compared on a point-by-point basis, where a random set of about 300 points were randomly generated throughout the studied area. Then using the aerial photos and the other resources of data, the land cover for each point was identified. After that, the same random points were used to identify each point's known land cover in the classified image. The error matrix table was completed by comparing these two values.

Cohen's kappa co-efficient was also calculated from the error matrix. Kappa coefficient is an important component of accuracy assessment that tells us how well the classification process was performed as compared to randomly assigning values [10].

\subsection{Change Detection of Agricultural Areas}

Change detection maps were simply generated by subtracting the (NDVI, SAVI and TNDVI) binary image for each two successive years. We have got seven types of change, which are:

1. agricultural to excluded areas;

2. barren to excluded;

3. agricultural to barren;

4. no change;

5. excluded to barren;

6. barren to agricultural

7. Excluded to agricultural.

The objective of applying change detection was to locate areas with changes in agricultural lands that took place over time in Diwaniyah Governorate. 


\subsection{Water consumption}

Diwaniyah is considered as one of the major Governorates in agricultural production. It is located in a climate zone which is proper for agriculture activities. This is in addition to its high soil fertility and availability of water resources. About of $3350 \mathrm{~km}^{2}$ of Diwaniyah Governorate is an arable land, which represents about $41 \%$ of the total area. Orchids, forests and bare lands represent about 83, 391 and 563 $\mathrm{km}^{2}$, respectively. Irrigated areas represent about $2895 \mathrm{~km}^{2}$, rainfed areas about 104 $\mathrm{km}^{2}$ and groundwater irrigated areas represent about $24 \mathrm{~km}^{2}$ [5].

\subsubsection{Water resources}

The irrigation system in Diwaniyah Governorate consists of two old types of irrigation networks:

1 - Irrigation and drainage network.

2 - Irrigation pumping system.

The major sources of surface water in the Governorate are Diwaniyah River, Shamiya River, Euphrates River and Basrughia River as shown in table (2)and figure (4) [5].

Table 2.Major sources of surface water and their discharge in Diwanyiah Governorate [5].

\begin{tabular}{|l|l|l|}
\hline River name & Length in Diwaniyah $(\mathbf{k m})$ & Discharge $\left(\mathrm{m}^{3} / \mathbf{s}\right)$ \\
\hline Diwaniyah River & $\mathbf{1 3 0}$ & $\mathbf{5 8 . 5}$ \\
\hline Shamiya River & $\mathbf{8 0}$ & $\mathbf{7 9}$ \\
\hline Euphrates River & $\mathbf{7 8}$ & 177.5 \\
\hline Basrughia River & $\mathbf{5 5}$ & $\mathbf{5 . 5}$ \\
\hline Total & $\mathbf{3 4 3}$ & $\mathbf{3 2 0 . 5}$ \\
\hline
\end{tabular}

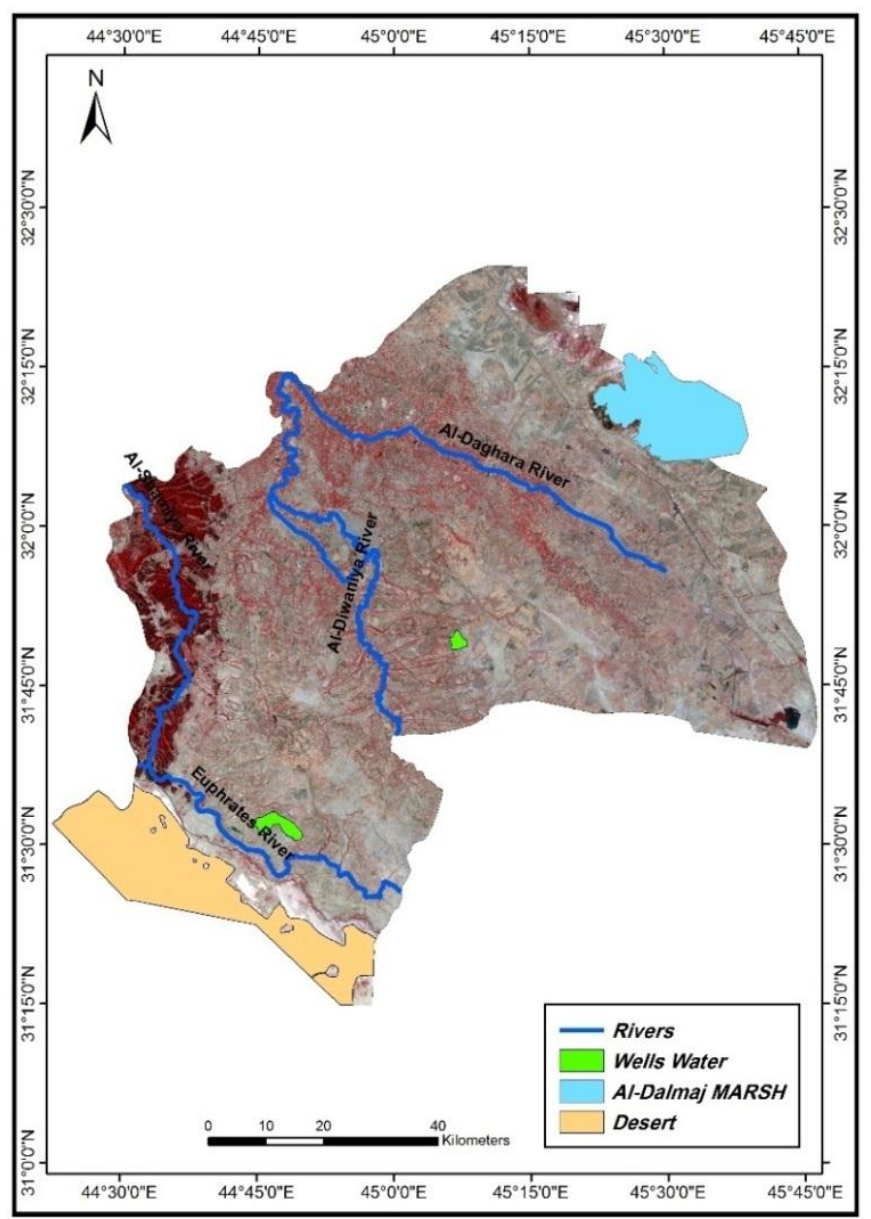

Figure.4. Major sources of surface water in Diwanyiah Governorate. 


\subsubsection{Water Resources Demand}

Demand of water supply for both the current and the future activities was assessed in this work. Water supply for domestic, agricultural and industrial activities was calculated by using an appropriate mathematical model as described briefly below:

\section{1- Domestic Demand}

Domestic demand is determined from population and per-capita water consumption, both specified for individual years. Bulk demand for industries is not included as a separate demand but is located within the respective settlement and is specified as a daily rate for individual years [11]. Per capita demand is specified in $1 / d$ and it is derived from the following equations:

$\mathrm{DWS}_{1}=\mathrm{POP}^{*} \mathrm{PCD}^{*} \mathbf{1 0}^{-3}$

(4)BULK $=0.05 * \mathrm{DWS}_{1}$

DWS $=$ DWS $_{1}+$ Bulk

Where:

DWS $_{1}$ : requested demand for water supply (cubic meters per day (cmd))

POP: population

PCD: per capita daily gross water need $(1 / d)$

BULK: bulk demand (cmd)

Demand constraints relate to the capacity of the water supply distribution and storage system to deliver the requested demand to the customers. This constraint, expressed as a value [cmd] for a certain year. The population in both urban and rural areas in Diwaniyah Governorate was calculated based on the data obtained from Central Agency for Public Mobilization and Statistics (CAPMS) in 2011 by using a $4 \%$ population increase rate. Accordingly, estimated population in urban areas was about 726,750 people in 2014 people and about 548,250 people in rural areas as shown in table (3). Per capita consumption in Diwaniyah Governorate is considered very high according to the UN standards (360 liter/capita/day for urban areas and 220 liter/capita/day for rural areas).

Table (3): Estimated Population for urban and rural areas in Diwaniyah Governorate at 2014 and 2033.

\begin{tabular}{|l|l|l|l|l|l|}
\hline \multirow{2}{*}{ Year } & Urban & Rural & \multirow{2}{*}{ Total } \\
\cline { 2 - 6 } & Population & \% & Population & \% & \\
\hline $\mathbf{2 0 1 4}$ & $\mathbf{7 2 6 7 5 0}$ & $\mathbf{5 7}$ & $\mathbf{5 4 8 2 5 0}$ & $\mathbf{5 7}$ & $\mathbf{1 2 7 5 0 0 0}$ \\
\hline $\mathbf{2 0 3 3}$ & $\mathbf{1 1 6 3 2 7 3}$ & $\mathbf{4 3}$ & $\mathbf{8 7 7 5 5 7}$ & $\mathbf{4 3}$ & $\mathbf{2 0 4 0 8 3 0}$ \\
\hline
\end{tabular}

\section{2- Agriculture Demand}

Water requirements for Agricultural crops are calculated in a similar manner to forest areas, except that more crops are considered. The gross water requirement for crops was calculated from net crop consumptive use of individual crops, percentages of the crops within a crop mix and irrigation efficiency as follows [11]:

DAG $=\Sigma\{\operatorname{Max}(0, \Sigma[($ Qnet $* p) *$ Area * (10/ eff)])\}

Where:

DAG: Demand for agricultural is the sum of the demands of individual farm units $\left(\mathrm{m}^{3} / \mathrm{d}\right)$

Qnet: Net irrigation requirement for individual crop $(\mathrm{mm} / \mathrm{d})$ p: Percentage of crop within crop mix (ranges from 1 to 100)

Area: Area of farm unit (ha)

eff: Irrigation efficiency (ranges from 1 to 100).

In Iraq the water requirement for any of the agricultural crops is estimated by 6300 $\mathrm{m}^{3} /$ Iraqi donam $\left(2,250,000 \mathrm{~m}^{3} / \mathrm{km}^{2}\right)[12]$.

\section{Results and Discussions}

4.1. Spatial Distribution of Agricultural vs. non-agricultural areas in Diwaniyah Governorate. 4.1.1. Spatial Distribution based on the NDVI index:

Spatial distribution of agricultural lands in Diwaniyah Governorate based on the NDVI index in 1985, 1992, 2002 and 
2014 is represented in table (4) and figure (5). Estimated agricultural lands were about 941, 1277, 1319 and $1132 \mathrm{~km}^{2}$ in 1985, 1992, 2002 and 2014, respectively and their percentages were about 10.71, $14.53,15.02$ and $12.89 \%$, respectively. On the other hand, non-agricultural lands (Barren) were about 7709, 7246, 7424 and $7387 \mathrm{~km}^{2}$ in 1985, 1992, 2002 and 2014, respectively and their percentages were about 87.74, 82.47, 84.50 and $84.08 \%$, respectively. The excluded areas were about 136, 263, 43 and $267 \mathrm{~km}^{2}$, respectively and their percentages were about 1.55, 2.99, 0.49 and $3.03 \%$, respectively. These results indicate that non-agricultural areas were significantly increased in Diwaniyah Governorate from 2002 to 2014 mainly due to the increase in population and urbanization. This increase in non-agricultural areas was on the account of agricultural areas, which were significantly decreased.

Table (4): Agricultural lands and their percentage in Diwaniyah Governorate from 1985 to 2014 based on the NDVI index.

\begin{tabular}{|c|c|c|c|c|c|c|c|c|}
\hline \multirow[b]{2}{*}{ Class } & \multicolumn{2}{|l|}{1985} & \multicolumn{2}{|l|}{1992} & \multicolumn{2}{|l|}{2002} & \multicolumn{2}{|l|}{2014} \\
\hline & $\begin{array}{l}\text { Area } \\
\mathbf{k m}^{2}\end{array}$ & $\%$ & $\begin{array}{l}\text { Area } \\
\mathbf{k m}^{\mathbf{2}}\end{array}$ & $\%$ & $\begin{array}{l}\text { Area } \\
\mathbf{k m}^{2}\end{array}$ & $\%$ & $\begin{array}{l}\text { Area } \\
\mathbf{k m}^{2}\end{array}$ & $\%$ \\
\hline Agric. & 941 & 10.71 & 1277 & 14.53 & 1319 & 15.02 & 1132 & 12.89 \\
\hline Non-agric. & 7709 & 87.74 & 7246 & 82.47 & 7424 & 84.50 & 7387 & 84.08 \\
\hline Excluded & 136 & 1.55 & 263 & 2.99 & 43 & 0.49 & 267 & 3.03 \\
\hline Total & 8786 & 100 & 8786 & 100 & 8786 & 100 & 8786 & 100 \\
\hline
\end{tabular}

Table (5): Agricultural lands and their percentage in Diwaniyah Governorate from 1985 to 2014 based on the SAVI index.

\begin{tabular}{|c|c|c|c|c|c|c|c|c|}
\hline \multirow[b]{2}{*}{ Class } & \multicolumn{2}{|l|}{1985} & \multicolumn{2}{|l|}{1992} & \multicolumn{2}{|l|}{2002} & \multicolumn{2}{|l|}{2014} \\
\hline & $\begin{array}{l}\text { Area } \\
\mathbf{k m}^{2} \\
\end{array}$ & $\%$ & $\begin{array}{l}\text { Area } \\
\text { km }^{2}\end{array}$ & $\%$ & $\begin{array}{l}\text { Area } \\
\mathbf{k m}^{2}\end{array}$ & $\%$ & $\begin{array}{r}\text { Area } \\
\mathbf{k m}^{2} \\
\end{array}$ & $\%$ \\
\hline Agric. & 1175 & 13.38 & 776 & 8.83 & 1119 & 12.74 & 1182 & 13.45 \\
\hline Non-Agric. & 7474 & 85.06 & 7747 & 88.17 & 7624 & 86.77 & 7338 & 83.50 \\
\hline Excluded & 137 & 1.56 & 263 & 3.00 & 43 & 0.49 & 266 & 3.05 \\
\hline Total & 8786 & 100 & 8786 & 100 & 8786 & 100 & 8786 & 100 \\
\hline
\end{tabular}

Table (6): Agricultural lands and their percentage in Diwaniyah Governorate from 1985 to 2014 based on the TNDVI index.

\begin{tabular}{|c|c|c|c|c|c|c|c|c|}
\hline \multirow[b]{2}{*}{ Class } & \multicolumn{2}{|l|}{1985} & \multicolumn{2}{|l|}{1992} & \multicolumn{2}{|l|}{2002} & \multicolumn{2}{|l|}{2014} \\
\hline & $\begin{array}{l}\text { Area } \\
\mathbf{k m}^{2}\end{array}$ & $\%$ & $\begin{array}{l}\text { Area } \\
\mathbf{k m}^{2}\end{array}$ & $\%$ & $\begin{array}{l}\text { Area } \\
\mathbf{k m}^{2}\end{array}$ & $\%$ & $\begin{array}{l}\text { Area } \\
\mathbf{k m}^{2}\end{array}$ & $\%$ \\
\hline Agric. & 764 & 8.69 & 978 & 11.14 & 919 & 10.46 & 1189 & 13.53 \\
\hline Non-Agric. & 7862 & 89.48 & 7454 & 84.83 & 7824 & 89.05 & 7287 & 82.94 \\
\hline Excluded & 160 & 1.82 & 354 & 4.03 & 43 & 0.49 & 310 & 3.52 \\
\hline Total & 8786 & 100 & 8786 & 100 & 8786 & 100 & 8786 & 100 \\
\hline
\end{tabular}




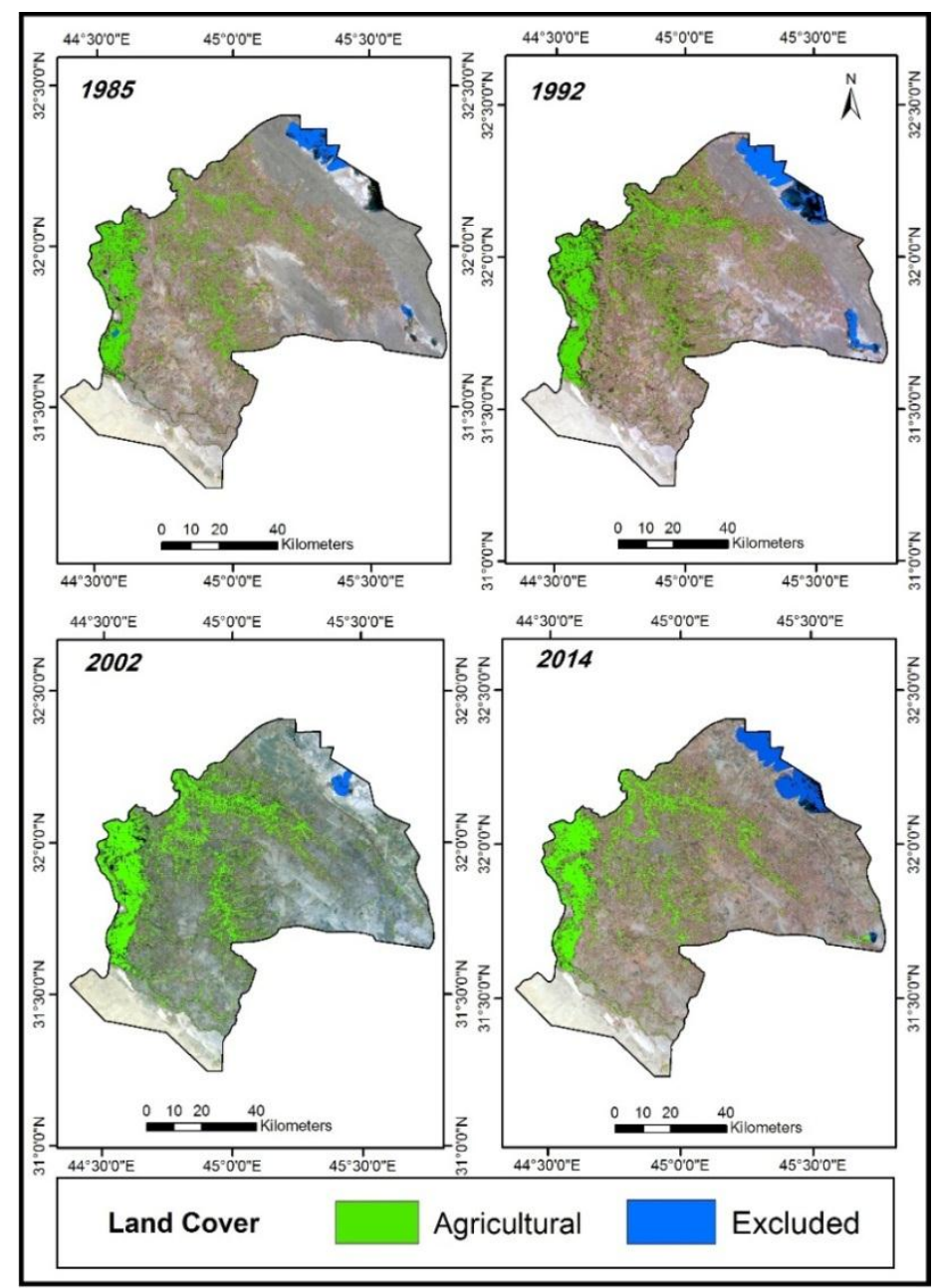

Figure (5): Spatial Distribution of agricultural vs. non-agricultural areas in Diwaniyah Governorate based on NDVI index in 1985, 1992, 2002 and 2014.

\subsubsection{Spatial Distribution based on the} SAVI index:

Spatial distribution of agricultural lands in Diwaniyah Governorate based on the SAVI index in 1985, 1992, 2002 and 2014, is illustrated in table 5 and figure (6). Agricultural areas were about 1175 , 776,1119 and $1182 \mathrm{~km}^{2}$ in 1985,1992 , 2002 and 2014, respectively and their percentages were about $13.38,8.83,12.74$ and $13.46 \%$, respectively. However, nonagricultural areas were about 7474,7747 , 7624 and $7338 \mathrm{~km}^{2}$ in 1985, 992, 2002 and
2014, respectively and their percentages were about $85.06,88.17,86.77$ and 83.50 $\%$, respectively. The excluded areas and their percentages were the same as that with the NDVI index. These results indicate that agricultural areas were increased in Diwaniyah Governorate during the studied period of time, however the significant increase was observed after 2014. This could be due to the enhancement in the equipment's used in agricultural production. 


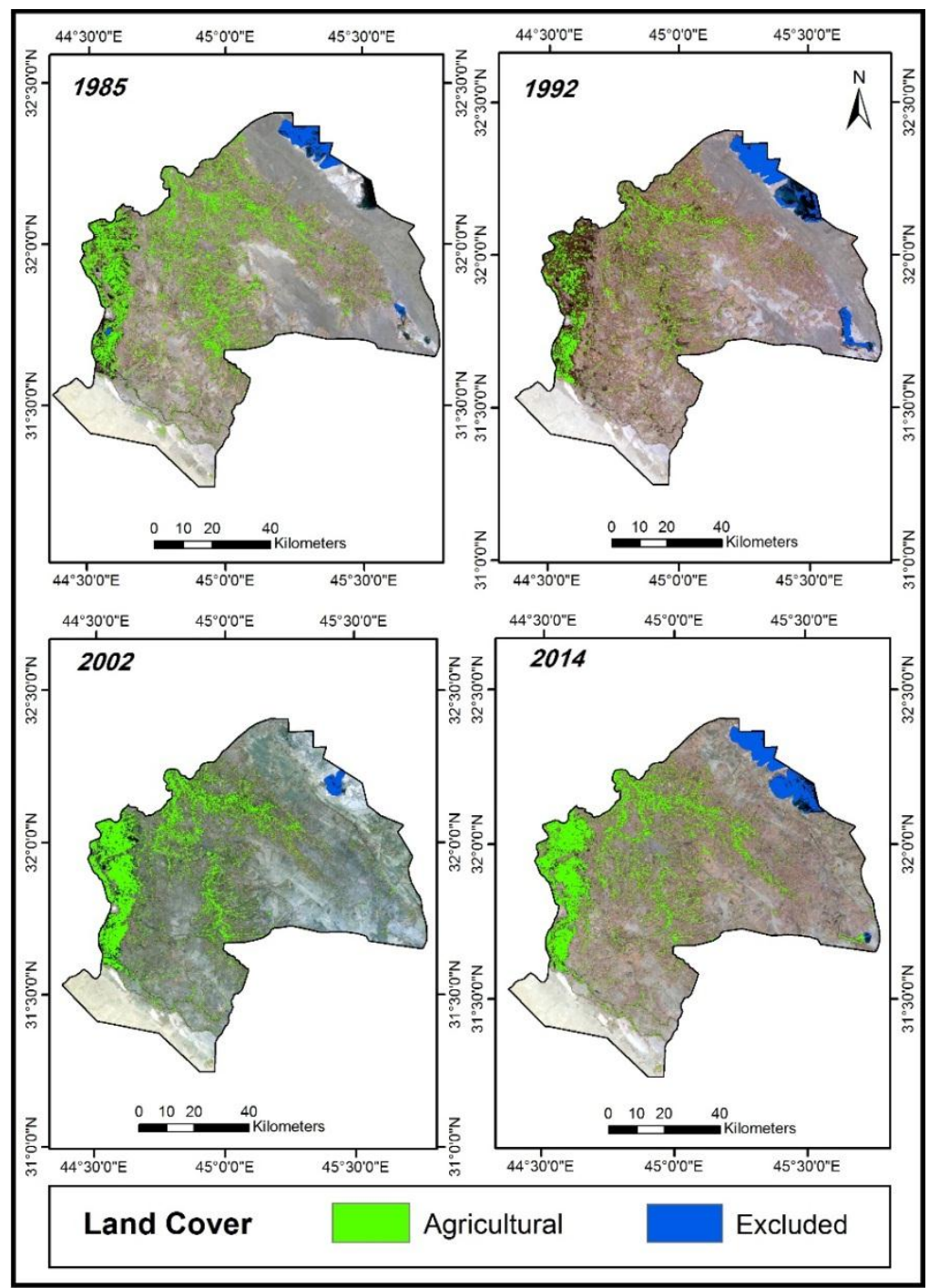

Figure (6): Spatial Distribution of agricultural vs. non-agricultural areas in Diwaniyah Governorate based on SAVI index in 1985, 1992, 2002 and 2014

\subsubsection{Spatial Distribution Based on the TNDVI index:}

Spatial distribution of agricultural lands in Diwaniyah Governorate based on the TNDVI index in 1985, 1992, 2002 and 2014 is demonstrated in table (6) and figure (7). Agricultural areas were about 764, 978, 919 and $1189 \mathrm{~km}^{2}$ in 1985 , 1992, 2002 and 2014, respectively and their percentages were about $8.69,11.14$,
10.46 and $13.53 \%$, respectively. Nonagricultural areas were about 7862, 7454, 7824 and $7287 \mathrm{~km}^{2}$ in 1985, 1992, 2002 and 2014, respectively and their percentages were about 89.48, 84.83, 89.05 and 82.94, respectively. Similar trends were observed among the three studied indices. 


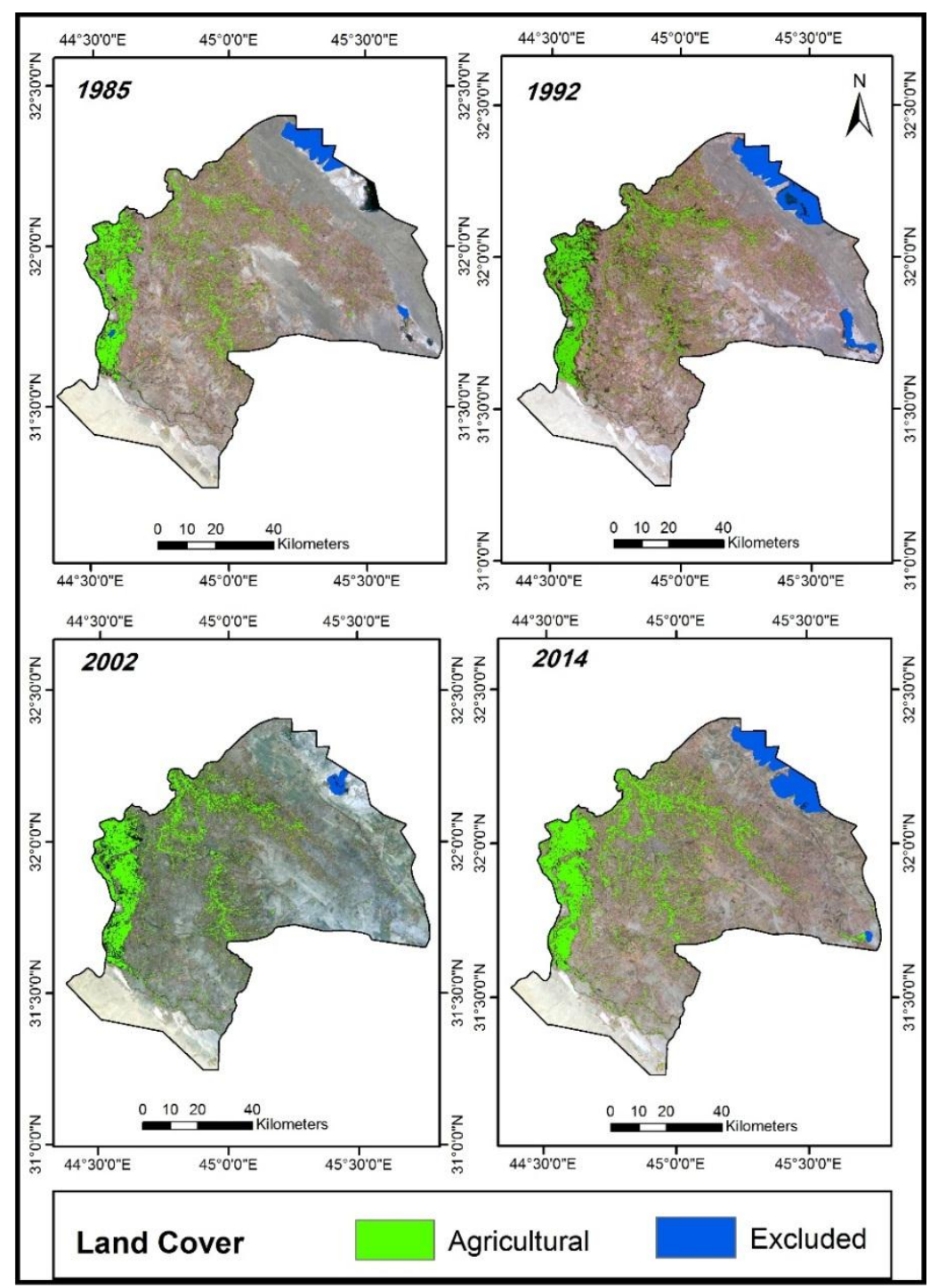

Figure (7): Spatial Distribution of agricultural vs. non-agricultural areas in Diwaniyah Governorate based on TNDVI index in 1985, 1992, 2002 and 2014

\subsection{Accuracy assessment of the studied indices:}

Accuracy Assessment was carried out on the obtained binary imaged from the three studied indices (NDVI, SAVI, and TNDVI) in 1985, 1992, 2002, and 2014 to evaluate the efficiency of each index in accomplishing the land cover classification process. In this process the classified images were compared with the actual land cover for each year. Three types of accuracies were calculated, which are producer's, user's and overall accuracy as represented in table (7). This was in addition to Cohen's kappa coefficient for each index. It was observed that land cover in the studied area was classified with high accuracy using the three studied indices. Data in Table (5) show that the lowest Producer's Accuracy for agricultural areas was $84.69 \%$ in 2002 with the NDVI, whereas the highest was $99.12 \%$ in 2014 with the TNDVI. The average values for Producer's accuracy of agricultural areas were 92.91, 95.97 and $97.73 \%$ for the NDVI, SAVI and the TNDVI, respectively. The lowest Producer's Accuracy for non-agricultural areas was $97.07 \%$ in 2002 with the SAVI and the 
highest was $100 \%$ in 2000 with the TNDVI. The average values for Producer's Accuracy of non-agricultural areas were 98.1, 97.9 and $99.45 \%$ for the NDVI, SAVI and the TNDVI, respectively. The lowest User's Accuracy for agricultural areas was $92.77 \%$ in 2002 with the SAVI, whereas the highest was $99.12 \%$ in 2014 with the TNDVI. The average values for User's Accuracy of agricultural areas were 96.13, 95.85 and $98.97 \%$ for the NDVI, SAVI and the TNDVI, respectively. The lowest User's Accuracy for nonagricultural areas was $92.57 \%$ in 2002 with the NDVI and the highest was $99.42 \%$ in 2014 with the TNDVI. The average values for User's Accuracy of nonagricultural areas were 96.71, 97.97 and $98.81 \%$ for the NDVI,

SAVI and the TNDVI, respectively. The lowest overall accuracy for the NDVI was $93.75 \%$ in 2002 and the highest was $98.23 \%$ in 2014 , with an average value of $96.47 \%$. The lowest Overall accuracy for the SAVI was $95.83 \%$ in 2002 and the highest was $98.95 \%$ in 2014 , with an average value of $97.275 \%$. Also, the lowest overall accuracy for the TNDVI was $98.28 \%$ in 2002 and the highest was $99.3 \%$ in 2014 , with an average value of $98.86 \%$.The obtained results also indicate that the lowest Kappa coefficient for the NDVI was 0.86 in 2002 and the highest was 0.96 in 2014, with an average value of 0.92. The lowest Kappa coefficient for the SAVI was 0.90 in 2002 and the highest was 0.98 in 2014, with an average value of 0.94. Also, the lowest Kappa coefficient for the TNDVI was 0.96 in 2002 and the highest was 0.99 in 2014, with an average value of 0.977 . It could be concluded from the accuracy assessment results that land cover in the studied area were classified with high accuracy. However, the TNDVI index had the highest accuracy when compared with the two other indices.

Table (7): Accuracy assessment for the obtained binary images by the NDVI, TNDVI and SAVI from 1985 to 2014.

\begin{tabular}{|c|c|c|c|c|c|c|}
\hline Year & Index & Class & $\begin{array}{l}\text { Producer's } \\
\text { Accuracy }\end{array}$ & $\begin{array}{l}\text { User's } \\
\text { Accuracy }\end{array}$ & $\begin{array}{l}\text { Overall } \\
\text { Accuracy }\end{array}$ & Kарра \\
\hline \multirow{3}{*}{1985} & NDVI & $\begin{array}{l}\text { Agric. } \\
\text { Non-Agric. }\end{array}$ & \begin{tabular}{|l|}
96.12 \\
98.31 \\
\end{tabular} & \begin{tabular}{|l|l|}
97.06 \\
97.75 \\
\end{tabular} & 97.50 & 0.95 \\
\hline & SAVI & $\begin{array}{l}\text { Agric. } \\
\text { Non-Agric. }\end{array}$ & $\begin{array}{l}97.92 \\
98.37\end{array}$ & $\begin{array}{l}96.91 \\
98.91\end{array}$ & 98.21 & 0.96 \\
\hline & TNDVI & $\begin{array}{l}\text { Agric. } \\
\text { Non-Agric. }\end{array}$ & $\begin{array}{l}99.10 \\
99.42 \\
\end{array}$ & $\begin{array}{l}99.10 \\
99.42 \\
\end{array}$ & 99.29 & 0.99 \\
\hline \multirow{3}{*}{1992} & NDVI & $\begin{array}{l}\text { Agric. } \\
\text { Non-Agric. }\end{array}$ & $\begin{array}{l}91.67 \\
98.08\end{array}$ & $\begin{array}{l}94.29 \\
97.14\end{array}$ & 96.43 & 0.91 \\
\hline & SAVI & $\begin{array}{l}\text { Agric. } \\
\text { Non-Agric. }\end{array}$ & $\begin{array}{l}94.12 \\
97.32 \\
\end{array}$ & $\begin{array}{l}95.52 \\
96.46\end{array}$ & 96.11 & 0.92 \\
\hline & TNDVI & $\begin{array}{l}\text { Agric. } \\
\text { Non-Agric. }\end{array}$ & $\begin{array}{l}97.67 \\
98.97\end{array}$ & $\begin{array}{l}97.67 \\
98.97 \\
\end{array}$ & 98.57 & 0.97 \\
\hline \multirow{3}{*}{2002} & NDVI & $\begin{array}{l}\text { Agric. } \\
\text { Non-Agric. }\end{array}$ & $\begin{array}{l}84.69 \\
98.42 \\
\end{array}$ & $\begin{array}{l}96.51 \\
92.57 \\
\end{array}$ & 93.75 & 0.86 \\
\hline & SAVI & $\begin{array}{l}\text { Agric. } \\
\text { Non-Agric. }\end{array}$ & \begin{tabular}{|l|l|}
92.77 \\
97.07 \\
\end{tabular} & \begin{tabular}{|l|l|}
92.77 \\
97.07 \\
\end{tabular} & 95.83 & 0.90 \\
\hline & TNDVI & $\begin{array}{l}\text { Agric. } \\
\text { Non-Agric. }\end{array}$ & $\begin{array}{l}95.05 \\
100.00\end{array}$ & $\begin{array}{l}100.00 \\
97.42 \\
\end{array}$ & 98.28 & 0.96 \\
\hline \multirow{3}{*}{2014} & NDVI & $\begin{array}{l}\text { Agric. } \\
\text { Non-Agric. }\end{array}$ & \begin{tabular}{|l|l|}
99.15 \\
97.59 \\
\end{tabular} & $\begin{array}{l}96.67 \\
99.39\end{array}$ & 98.23 & 0.96 \\
\hline & SAVI & $\begin{array}{l}\text { Agric. } \\
\text { Non-Agric. }\end{array}$ & \begin{tabular}{|l|l|}
99.10 \\
98.85 \\
\end{tabular} & $\begin{array}{l}98.21 \\
99.42\end{array}$ & 98.95 & 0.98 \\
\hline & TNDVI & $\begin{array}{l}\text { Agric. } \\
\text { Non-Agric. }\end{array}$ & $\begin{array}{l}99.12 \\
99.42 \\
\end{array}$ & $\begin{array}{l}99.12 \\
99.42 \\
\end{array}$ & 99.30 & 0.99 \\
\hline
\end{tabular}


4.3. Changes of land covering Diwaniyah Governorate from 1985 to 2014 Based on the TNDVI index:

Data in figures (8) and (9) show the changes of land cover in Diwaniyah Governorate between 1985 and 2014 based on the TNDVI index. The obtained results indicated that about $86.5 \%$ hadn't any change in land cover. However, the most obvious change was from barren to agricultural lands by about $700 \mathrm{~km}^{2}$ (about $7.97 \%$ of the studied area), which could be due to land reclamation projects in the north-eastern parts of the Governorate (The main drainage project). This is followed by the changes from agricultural to Barren lands by about $277 \mathrm{~km}^{2}$ (3.15\% of the area), which could be due to urbanization or leaving agricultural lands without cultivation. The other change was from barren to excluded by about $178 \mathrm{~km}^{2}$ (about $2.03 \%$ of the studied area), which could be due to water logging of some areas close to Al-Dalmaj marsh. Nosignificant changes were found from agricultural to excluded and vice versa. Similar trends were observed among the other studied periods from 1985 to 1992 , 1992 to 2002 and from 2002 to 2014 as represented in table 8 .

Table (8): Changes in land cover in Diwaniyah Governorate between1985 and 2014.

\begin{tabular}{|c|c|c|c|c|c|c|c|c|}
\hline \multirow{2}{*}{$\begin{array}{l}\text { Change in } \\
\text { Land cover }\end{array}$} & \multicolumn{2}{|c|}{$1985-1992$} & \multicolumn{2}{|c|}{$1992-2002$} & \multicolumn{2}{|c|}{$2002-2014$} & \multicolumn{2}{|c|}{$1985-2014$} \\
\hline & $\mathbf{k m}^{2}$ & $\%$ & $\mathbf{k m}^{2}$ & $\%$ & $\mathbf{k m}^{2}$ & $\%$ & $\mathbf{k m}^{2}$ & $\%$ \\
\hline $\begin{array}{l}\text { Agric. to } \\
\text { excluded }\end{array}$ & 1 & 0.01 & $\mathbf{0}$ & 0.00 & $\mathbf{0}$ & 0.00 & $\mathbf{0}$ & 0.00 \\
\hline $\begin{array}{l}\text { Barren to } \\
\text { Excluded } \\
\end{array}$ & 203 & 2.31 & 0 & 0.00 & 265 & 3.01 & 178 & 2.03 \\
\hline $\begin{array}{l}\text { Agric. to } \\
\text { Barren } \\
\end{array}$ & 357 & 4.06 & 511 & 5.81 & 289 & 3.29 & 277 & 3.15 \\
\hline No change & 7648 & 87.05 & 7500 & 85.37 & 7674 & 87.34 & 7601 & 86.51 \\
\hline $\begin{array}{l}\text { Excluded to } \\
\text { Barren }\end{array}$ & 6 & $\mathbf{0 . 0 7}$ & 322 & 3.67 & 0 & 0.00 & 27 & $\mathbf{0 . 3 1}$ \\
\hline $\begin{array}{l}\text { Barren to } \\
\text { Agric. }\end{array}$ & 567 & 6.45 & 453 & 5.16 & 558 & 6.36 & 700 & 7.97 \\
\hline $\begin{array}{l}\text { Excluded to } \\
\text { Agric. }\end{array}$ & 4 & 0.05 & 0 & 0.00 & 0 & 0.00 & 3 & $\mathbf{0 . 0 3}$ \\
\hline Total & 8786 & 100 & 8786 & 100 & 8786 & 100 & 8786 & 100 \\
\hline
\end{tabular}

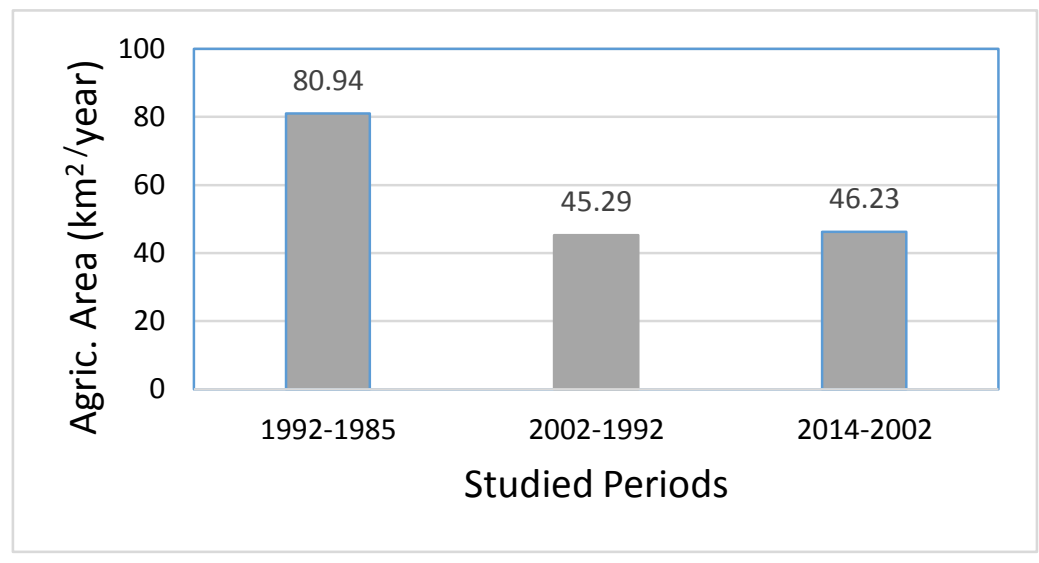

Figure (8): Annual increase in agricultural areas at Diwaniyah Governorate from 1985 to 2014 based on the TNDVI index. 


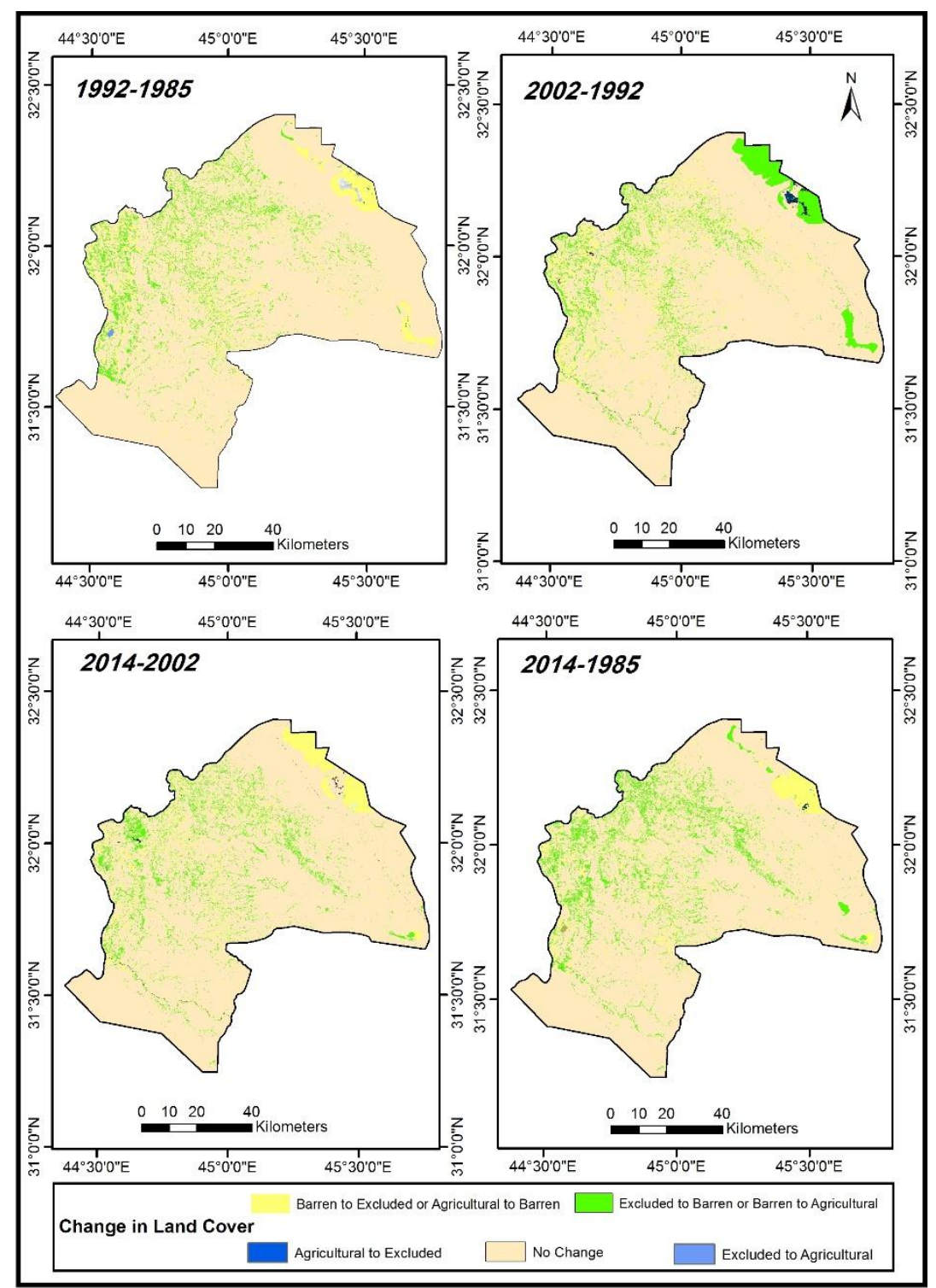

Figure (9): Changes of land cover in Diwaniyah Governorate from 1985 to 2014 based on the TNDVI index

\subsection{Water supply and demand}

Data in table (9) represent the amounts of water supply for Diwaniyah Governorate and water demand for all activities in both in 2014 and the targeted year (2033). Water budget (supply) for Diwaniyah Governorate is about 10,107 million cubic meters per year [5]. This amount is distributed among the different human activities in the Governorate. It was found that domestic demand for drinking and industrial activities in urban areas was about 100 million $\mathrm{m}^{3} /$ year in 2014 ; however this amount is expected to increase to about 153 million $\mathrm{m}^{3} /$ year in 2033. Domestic demand for human uses and industrial activities in rural areas was about 46 million $\mathrm{m}^{3} /$ year in 2014 and it is expected to increase to about 70 million $\mathrm{m}^{3} /$ year in 2033. Agricultural areas were estimated by $1189 \mathrm{~km}^{2}$ in 2014 according to the TNDVI. Rain fed and groundwater irrigated areas were subtracted from that area and the resulted area was $1061 \mathrm{~km}^{2}$. 
Water demand for both agricultural and forest areas was estimated by about 2,387 million $\mathrm{m}^{3} /$ year in 2014 . It was assumed that all the arable lands $\left(3350 \mathrm{~km}^{2}\right)$ are going to be cultivated by 2033 . Accordingly, the water demand for these areas is expected to be increased to about 8,442 million $\mathrm{m}^{3} /$ year. Water loss from the conveying canals due to seepage and evaporation is estimated by about $40 \%$ according to the [12].

As a result about 4,036 million $\mathrm{m}^{3}$ from water supply is lost per year in both 2014 and 2033. Net water demand was estimated by about 2,387 million $\mathrm{m}^{3} /$ year in 2014 and about 8,665 million $\mathrm{m}^{3} /$ year in 2033. Accordingly, a surplus in water supply is expected in 2014 by about 3,531 million $\mathrm{m}^{3}$, however a shortage in water supply is expected in 2033 by about 2,601 million $\mathrm{m}^{3}$. These results raise the concern about maintaining water resources, looking for other secondary resources and using more effective irrigation systems to minimize water loss, sustain agricultural land and production in the nearest future.

Table (9): Water demands for all activities in Diwaniyah Governorate in 2014 and 2033.

\begin{tabular}{|l|l|l|}
\hline Type & \multicolumn{2}{l|}{ Quantities $\left(\mathrm{m}^{3} /\right.$ year $)$} \\
\hline & $\mathbf{2 0 1 4}$ & $\mathbf{2 0 3 3}$ \\
\hline Surface water supply & $\mathbf{1 0 1 0 7 2 8 8 0 0 0}$ & $\mathbf{1 0 1 0 7 2 8 8 0 0 0}$ \\
\hline Domestic demand for urban areas & $\mathbf{1 0 0 2 6 9 6 9 8}$ & $\mathbf{1 5 2 8 5 4 0 7 2}$ \\
\hline Domestic demand for rural areas & $\mathbf{4 6 2 2 5 6 9 9}$ & $\mathbf{7 0 4 6 7 8 2 7}$ \\
\hline $\begin{array}{l}\text { Demand for agriculture and forestry (Cultivated area }=1061 \\
\text { km }^{2} \text { in 2014 and 3350 } \mathbf{k m}^{2} \text { in 2033) }\end{array}$ & $\mathbf{2 3 8 7 2 5 0 0 0 0}$ & $\mathbf{8 4 4 2 0 0 0 0 0 0}$ \\
\hline Water loss (40\% of water supply) $^{\text {Net water supply (water supply - 40\% water loss) }}$ & $\mathbf{4 0 3 6 6 0 8 0 0 0}$ & $\mathbf{4 0 3 6 6 0 8 0 0 0}$ \\
\hline $\begin{array}{l}\text { Water demand for all activities (urban, rural, agricultural and } \\
\text { industrial) }\end{array}$ & $\mathbf{6 0 6 4 3 7 2 8 0 0}$ & $\mathbf{6 0 6 4 3 7 2 8 0 0}$ \\
\hline Net remaining water & $\mathbf{2 5 3 3 7 4 5 3 9 7}$ & $\mathbf{8 6 6 5 3 2 1 8 9 9}$ \\
\hline
\end{tabular}

\subsection{Proposed Areas for land Reclamation}

From the obtained results and other criteria required for land reclamation (i.e., soil characteristics, availability and quality of irrigation water, labor force, infrastructure and security) two areas can be proposed for agricultural reclamation projects in Diwaniyah Governorate as represented in figure (10). The first area is to the south west of Almasab-Alaam drainage project, which is one of the major projects for land reclamation in Iraq. Four cities are located around that area, which are Diwaniyah, Afak, Albeder and Nufer. It covers an area of about $2029 \mathrm{~km}^{2}$ about $23 \%$ from total Diwaniyah Governorate area. However, only about $147.7 \mathrm{~km}^{2}$ of that area is currently cultivated. The second is to the south west of AlDiwaniyah River and it covers an area of about $442 \mathrm{~km}^{2}$ about $5 \%$ from total Diwaniyah Governorate area. About 49.3 $\mathrm{km}^{2}$ of that area is already cultivated. Two cities are located around that area (AlHamza Al-Sharqi and Al-Sadeer). Soils in Diwaniyah Governorate are generally developed on alluvial deposits, which are considered highly fertile soils. It was found that the annual increase in agricultural land was about $14.65 \mathrm{~km}^{2}$ per year from 1985 to 2014, however to cultivate the proposed area for reclamation by 2033 this rate has to be increased to 126 $\mathrm{km}^{2} /$ year. 


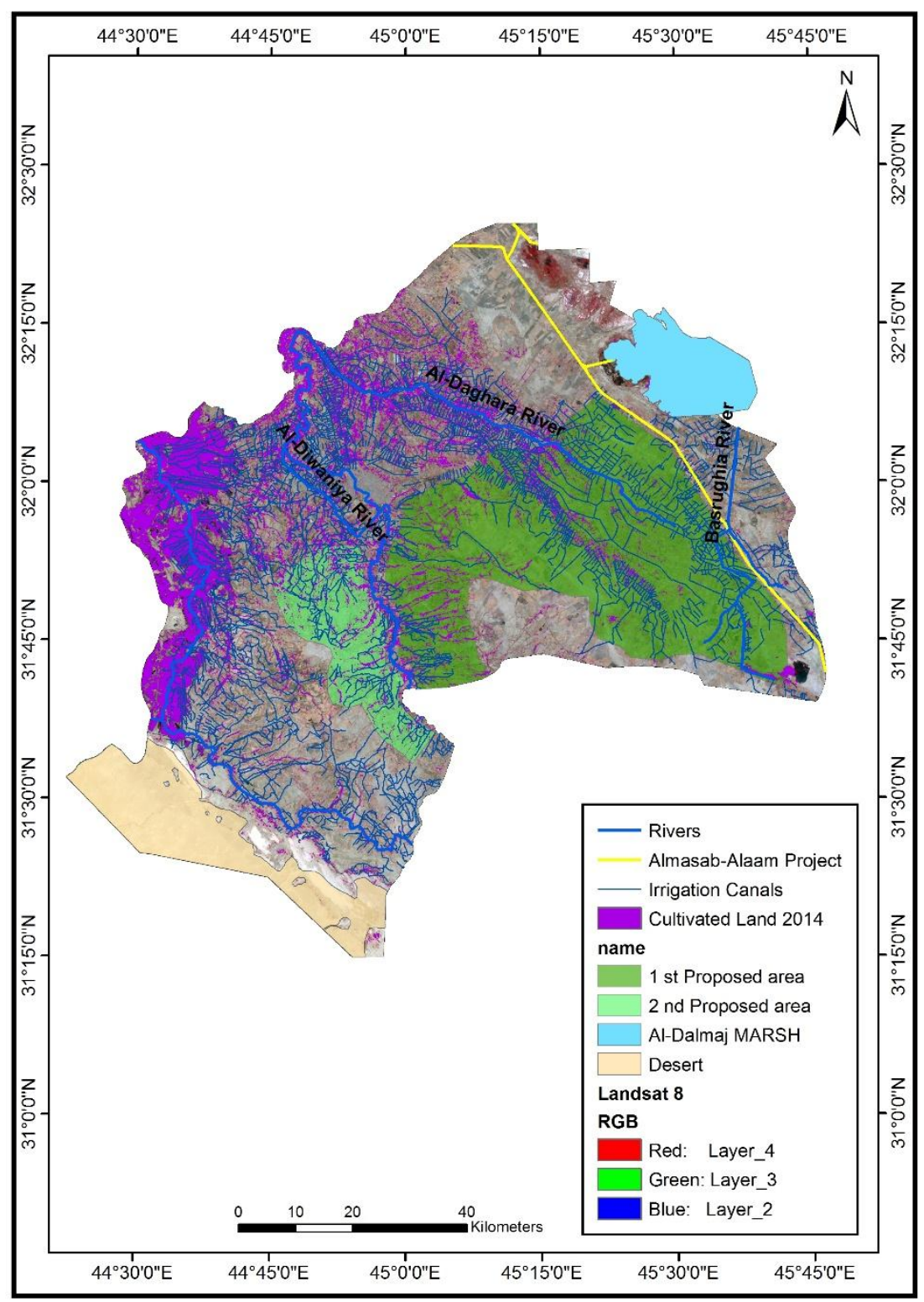

Figure (10): The Proposed Areas for land reclamation

\section{Conclusion}

It could be concluded that both remote sensing data and geographic information system could play an important role in studying and monitoring changes in land cover. They could provide more accurate, less expensive and timewise information.

Changes in agricultural areas were very active in the western parts of Diwaniyah Governorate mainly due to increase in population, urbanization and land reclamation projects. More concern needs to be given to agricultural projects to supply the increasing population with their urgent need to food.

A surplus in water supply was found in 2014; however a shortage in water resources is expected in 2033 if all the arable lands are going to be cultivated by that year. Accordingly, certain concerns have to be given to maintaining the current water resources to minimize water loss. This is in addition to looking for other secondary resources and using more effective irrigation systems to sustain 
agricultural production in the coming future.

Large areas can be proposed for land reclamation in Diwaniyah Governorate based on their soil properties, water availability and quality, labor force, infrastructure and security. Serious actions have to be taken to increase the annual rate for land reclamation by about $126 \mathrm{~km}^{2}$ / year to cultivate the proposed areas by 2033.

\section{References}

[1] Cetinkaya, G.,Kambu, A.and Nakamura, k. (2014). Sustainable Development and Natural Resource Management: an Example from KoprülüKanyon National Park, Turkey. Sust. Dev., 22: 63-72.

[2] Kates, R.W., Parris, T.M. and Leiserowitz, A.A. (2005). What's Sustainable Development? Goals, Indicators, Values, and Practice. Environ. Sci. and Policy for Sust. Dev., 47(3):8-21.

[3] Bhan, S.K., Saha, S. K., Pande, L. M. and Prasad, J. (2009).Use of Remote Sensing and GIS Technology in Sustainable Agricultural Management and Development. Indian experience, Indian Institute of Remote Sensing, NRSA (N.D.).

[4] IMOS (2014). Climatic data of Iraq. Iraqi Meteorological Organization and Seismology (IMOS). Ministry of Transportation. Downloaded in April 20 , 2015 from:http://meteoseism.gov.iq/index. php.
[5] MMPW (2014). Structural plan for Diwaniyah stage 5 report. Final report.Ministry of Municipalities and Public Works (MMPW), Iraq.

[6] Masek, J.G., Lindsay, F.E. and Goward, S.N. (2000). Dynamics of urban growth in the Washington, DC metropolitanarea 1973-1996 from Landsat observations. Int. J. of Rem. Sens., 21(18) 3473-3486.

[7] Senseman, G.M., Tweddale, S.A., Anderson, A.B. and Bagley, C. F. (1996).Correlation of land condition trend analysis (LCTA) rangeland cover measures to satellite imageryderived vegetation. USACERL technical report 97/07, USA

[8] Huete, A. R. (1988). A SoilAdjusted Vegetation Index (SAVI). J. Rem. Sens. of Envir., 25: 295-309.

[9] Xu, H. (2008). A new index for delineating built-up land features in satellite imagery.Int. J. of Rem. Sens., 29(14):4269-4276.

[10] Campbell, J.B. and Wynne, R.H. (2011). Introduction to Remote Sensing, $5^{\text {th }}$ Ed. The Guilford Press, New York, USA.

[11] Al-Mulla, M., Debebe, A.M., Sherif, M., Ebraheem, A.M., Saadullah, M.and M. Qaiser2010. A GIS Water Resources and Water Budget System for an Integrated Management of Water Resources in UAE. $9^{\text {th }}$ Gulf Water Conf.,March 22-25, Muscat, Sultanate of Oman.

[12] Al-Badry,B.H.(2010).The impact of the scarcity of water resources on irrigated agriculture in Iraq.J. of Manag. and Eco., Univ. of Mustansiriya, $\quad 80: \quad 127-128$ 